\title{
Proliferation Activity of Mucosal Epithelial Cell Nucleus With AgNOR Staining in Smokers and Non-Smokers
}

\author{
Wilda Hafni Lubis, Gowri A/P Krishnarao \\ Department of Oral Medicine \\ Faculty of Dentistry, Universitas Sumatera Utara \\ Medan, Indonesia \\ wilda_hafny_lubis@yahoo.com
}

\begin{abstract}
Oral cancer detection is difficult in the early stages leading to high mortality rate of the disease. Therefore, a new method of early detection of oral carcinoma is required as treatment in the early stages is more effective at minimizing morbidity. The purpose of this study was to examine the differences in cellular structure of AgNOR nuclear proliferation activity collected from normal buccal mucosa with cytology exfoliative techniques in smokers and non-smokers. Nucleolar Organizer Region (NOR) is a DNA that encodes RNA ribosomes and is considered essential in protein synthesis. Calculation of AgNOR is considered as an index to estimate the potential of cellular mitosis. This is a descriptive analytic research with cross sectional approach. Data were collected at the Oral Medicine Installation, RSGMP FKG USU and laboratory examination was performed at the Anatomical Pathology Laboratory, Faculty of Medicine USU in January and February 2014. The number of research subjects was 20 people. The data were obtained by questionnaires and clinical examination on the subjects who met the inclusion criteria. Data analysis is done by testing the hypothesis done on univariate data and bivariate data. The collected data were analyzed with Mann-Whitney statistical test and unpaired t-test. The results of this study indicated that there were significant differences to the count of AgNOR smokers and non-smokers. The proliferation activity of buccal mucosal epithelial cells using AgNOR dye smokers and non-smokers showed significant difference $(P=$ 0.0001). There is no significant relationship between the duration, type and number of cigarettes smoked per day. But the differences can be seen pathologically. In conclusion, there is a significant association between smoking and an increase in cell proliferation activity of the oral mucosa in smokers.
\end{abstract}

Keywords-smoking, oral mucosa, early detection, nucleolar organizer region

\section{INTRODUCTION}

The dangers of smoking to the body and health has been researched many times and it has been proven again and again that smoking habits are difficult to stop and rarely recognized as a bad habit, whereas the adverse effects of smoking are well known [1]. Smoking habit has been proven to cause almost 50 health problems and 20 of them are fatal to humans. In the United States, some studies suggested that smoking is the third largest cause of death, relating to lung cancer, coronary heart disease and chronic obstructive pulmonary disease [2,3].

Indonesia is one of the largest tobacco consuming countries in the world. In 2009, Indonesia was the fourth cigarette consumer in the world after China, the Russian Federation, and the United States [1]. The average age of smoking beginners is 17.4 years [4]. Smoking habits can also be associated with changes in the oral cavity $[5,6]$. The effects of tobacco use vary in the oral cavity depending on how it is used, and is different in each country. Pre-processing methods are also various, causing different effects of tobacco products in the oral cavity [7]. Changes seen in the oral cavity are most likely the result of irritants, toxins and carcinogens found naturally in tobacco being processed or burned. Smoking can cause disturbances locally in the oral cavity such as leukoplakia, stomatitis nikotina, smokers melanosis, coated tongue, hairy tongue, candidiasis, leukodema, tobacco keratosis, gingivitis, periodontitis, acute ulcerative gingivitis and oral cancer $[5,6,8]$

One of the most severe effects of smoking habits that occur in the buccal mucosa is the change of normal cells into malignant cells, called oral cancer [5]. Of all the factors that contribute to the etiology of oral cancer, tobacco use is said to be the most important factor [9]. The International Agency for Research on Cancer (IARC) said that all forms of tobacco such as bidis, pipes, cigars and cigarettes are carcinogenic in humans [10]. Cigarette use in reverse, i. e. 'reverse smoking', is associated with a higher risk of oral cancer [9].

Squamous Cell Carcinoma (SCC) is a malignant lesion type most commonly found in the world, with a percentage of more than $90 \%$ in all types of malignant lesions [11]. One of the risk factors that can cause SCC in the oral cavity is smoking. Many studies show that there were a causal relationship between smoking and the occurrence of Oral Squamous Cell Carcinoma (OSCC) [12]. The mortality rate caused by OSCC in Indonesia is $2.4 \%-3.57 \%$ [3]. Prognosis of OSCC is bad with a survival rate of only $56 \%$ and $41 \%$ at 5 and 10 years. OSCC is found more frequently in 
adult men over 40 years of age and the most common sites are in the lower lip, lateral tongue and floor of the mouth [11]

There is evidence suggesting that oral cavity is an easy place to examine, however it's difficult to detect OSCC in the early stage and almost all diagnosed patients died of the disease $[14,15]$. However, the ignorance or unavailability of the way of diagnosis, this cancer is often detected at an advanced stage. Therefore, a new method of early detection of oral carcinoma is required because treatment in the early stages is more effective at minimizing morbidity [10]. The current method is often used to obtain a diagnosis of the lesion by biopsy. The disadvantage of using it is that biopsy is only performed when the lesion becomes symptomatic or is present at an advanced stage [16]. Because early diagnosis is essential for OSCC, the cytology-exfoliative method, a simple, painless and inexpensive method has become the preferred method for making early diagnosis of lesions [12,17]. Exfoliative cytology is an easy, non-invasive procedure and can be used even if there is little suspicion about the nature of a lesion [16].

Nucleolar Organizer Regions (NOR), a loop of DNA that encode ribosomal RNA, is considered important in protein synthesis. NOR proteins are associated with non-histonic and argyrophilic acid that can be visualized as dark brown spots or black round spots in the nucleus by using silver coloring techniques in preparation routine histology and cytology preparations. Calculations of AgNOR are considered as an index to estimate the potential of cellular mitosis. Previous research has shown that AgNOR's quantitative and qualitative analysis is useful in determining the diagnosis and prognosis of most neoplasms [18]. Exfoliative cytology is rarely used to evaluate changes caused by cigarette smoke in the normal mucosa and most studies are performed on the role of AgNOR in early OSCC detection using the mouth and lateral bases of the tongue to take a smear sample. There were few studies conducted with smear samples of buccal mucosa, this study will take smear samples from the buccal mucosa of smokers and non-smokers. The purpose of this study was to determine the cellular structure of the nuclear proliferation activity with AgNOR of samples collected from normal buccal mucosa with exfoliative cytology techniques in smokers and non-smokers.

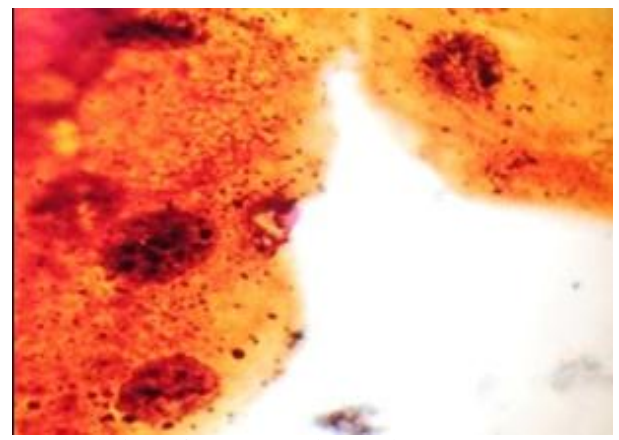

Figure 1. Calculation of 6 AgNOR in smokers.

\section{MATERIALS AND METHODS}

This research is descriptive analytic study conducted using cross-sectional approach to determine the effect of smoking habits to changes in the proliferative activity of nucleus. Cross-sectional approach meant that the research subjects were observed only once, i.e during the oral examination. The study was conducted at the Installation of Oral Medicine, RSGMP, Faculty of Dentistry, University of Sumatera Utara. The place was chosen as the old smoker population could be found in non-academic employee and the new smoker population could be found in the male students of FKG USU and the non-smoker population could be found among the male student of Faculty of Dentistry of USU. The population has good understanding of the objective of the research and were more cooperative.

This study has been approved by the Ethics Commission with letter No: 22 / KOMET / FKUSU / 2014. Total research subjects were 20 people. Inclusion criteria were men who had a habit of smoking more than 10 cigarettes per day for more than 10 years with good or moderate $\mathrm{OH}$ and a normal buccal mucosa. Men who have systemic and exclusive diseases that consume alcohol were excluded. Respondents who met the inclusion criteria were given an explanation about the study and informed consent was obtained. The buccal smear was obtained using cytobrush method. The obtained cells were applied to a rotating glass object then fixed with $96 \%$ alcohol and placed on top of the gauze to dry in the air. Dry glass object is sent to Anatomical Pathology Laboratory by using glass object storage box. Data collection was obtained by providing questionnaires and by performing clinical examination. AgNOR staining technique used was the method recommended by Ploton. The solution was prepared by mixing one volume of $2 \%$ gelatin in $1 \%$ formic acid and two volumes of liquid silver nitrate $50 \%$. All glazed objects were incubated with this solution for 30 minutes at room temperature in the dark medium and protected in the dark until analyzed.

After staining with AgNOR, the calculation of the number of AgNOR in 100 cells was first done by looking at the object glass that has been coated with oil immersion from left to right using a microscope with 1000x magnification. AgNOR calculations were performed 3 times repeatedly by different operators to avoid bias in the counting. Glass objects were evaluated for changes in the nucleus. Then the results were recorded. The Crocker method was used to calculate the black spots within the cell nucleus, the aggregation of black spots were counted as a structure and cells with no nucleus were excluded. The average value of AgNOR calculations and the standard deviation of AgNOR were calculated.

The data were analyzed using the Mann-Whitey and unpaired t-test. If statistical calculations shows $\mathrm{P}$ value of $<0.05$, then $\mathrm{h}_{0}$ that there is a significant relationship between the variables is denied. If the $\mathrm{P}$ value is $>0.05$ then $\mathrm{h}_{0}$ that there is no significant relationship between the two variables is accepted. 


\section{RESULTS}

The number of samples in this study was 15 students of Faculty of Dentistry, USU and 5 male nonacademic workers who had smoking habits and had no smoking habits.

In this study, the median age for the sample of smokers was 24.9 years and the mean age of nonsmokers was 21.8 years. The youngest smoker in the study was 23 years and the oldest smoker was 32 years. Most respondents with smoking habit were between the ages of 10-15 years old (80\%). Of all samples, only 2 samples had smoking habit of more than 15 years. Most samples smoked about 10-15 cigarettes per day. This group has the highest frequency with as many as 7 people $(70 \%)$. It was found that the frequency of cigarettes consumption was the same with white cigarettes consumption $(50 \%)$. There was a change of proliferative activity in the buccal mucosa (>3 AgNOR) in smokers by $100 \%$ and only $10 \%$ in non-smokers.

TABLE I. PERCENTAGE OF CHANGES IN PROLIFERATIVE ACTIVITY IN THE BUCCAL MUCOSA OF SMOKERS AND NON SMOKERS ( $>3$ AGNOR)

\begin{tabular}{|l|c|c|c|}
\hline $\begin{array}{c}\text { Changes in Activities of } \\
\text { Proliferation in the } \\
\text { Buccal Mucosa }\end{array}$ & $\begin{array}{c}\text { Total } \\
\text { (sample) }\end{array}$ & $\begin{array}{c}\text { Changed } \\
(\mathbf{n})\end{array}$ & $\begin{array}{c}\text { Percentage } \\
(\boldsymbol{\%})\end{array}$ \\
\hline Smoker & 10 & 10 & 100 \\
\hline Non-smoker & 10 & 1 & 10 \\
\hline
\end{tabular}

The data were analyzed using descriptive analysis with cross tabulation (cross-tab) to determine the significance level of smoking habits and changes in the proliferative activity in the buccal mucosa. The test used was the Mann-Whitney Test.

Table II shows a change in proliferative activity in the buccal mucosa ( $>4$ AgNOR) in smokers as much as $80 \%$ but the relationship of long-term smoking to the occurrence of changes in epithelial cell proliferation activity in the buccal mucosa was not significant with $\mathrm{P}$ $=1,000(\mathrm{P}<0,05)$.

TABLE II. THE RELATIONSHIP OF LONG- TERM SMOKING TO THE CHANGE IN EPITHELIAL CELL PROLIFERATION ACTIVITY IN THE BUCCAL MUCOSA (> 4 AGNOR)

\begin{tabular}{|c|c|c|c|c|}
\hline \multirow{2}{*}{$\begin{array}{c}\text { Duration } \\
\text { of Smoking }\end{array}$} & \multicolumn{2}{|c|}{$\begin{array}{c}\text { Changes of Proliferation } \\
\text { Activity in the Buccal Mucosa }\end{array}$} & \multirow{2}{*}{ Total } & \multirow{2}{*}{$\begin{array}{c}\text { P } \\
\text { value }\end{array}$} \\
\cline { 2 - 3 } & Yes & No & & \\
\hline $10-15$ years & $6(60 \%)$ & $2(20 \%)$ & 8 & \multirow{2}{*}{1.000} \\
\hline$>15$ years & $2(20 \%)$ & $0(0 \%)$ & 2 & \\
\hline
\end{tabular}

Table III shows a change of proliferation activity in the buccal mucosa (>4 AgNOR) in smokers by $80 \%$, but the relationship between the number of cigarettes smoked per day and the occurrence of changes in epithelial cell proliferation activity in the buccal mucosa was not significant with $\mathrm{P}=0.606(\mathrm{P}<0,05)$.

Table IV shows that there was a change in proliferative activity in the buccal mucosa ( $>4$ AgNOR) in smokers as much as $100 \%$ but the relationship of cigarettes smoked per day to the occurrence of changes in epithelial cell proliferation activity in the buccal mucosa was not significant with $\mathrm{P}=0.549(\mathrm{P}<0.05)$.
TABLE III. THE RELATIONSHIP BETWEEN THE NUMBER OF CIGARETTES SMOKED PER DAY AND THE OCCURRENCE OF CHANGES IN PROLIFERATION ACTIVITY IN BUCCAL MUCOSA (> 4 AGNOR)

\begin{tabular}{|c|c|c|c|c|}
\hline \multirow{2}{*}{$\begin{array}{c}\text { Number of } \\
\text { Cigarettes/ } \\
\text { Day }\end{array}$} & \multicolumn{2}{|c|}{$\begin{array}{c}\text { Changes of Proliferative } \\
\text { Activity in the Buccal } \\
\text { Mucosa }\end{array}$} & \multirow{2}{*}{ Total } & $\begin{array}{c}\text { P } \\
\text { Value }\end{array}$ \\
\cline { 2 - 4 } & Yes & No & & \\
\hline $10-15$ cigarettes & $6(60 \%)$ & $1(10 \%)$ & 7 & \multirow{2}{*}{0.606} \\
\hline $15-20$ cigarettes & $0(0 \%)$ & $1(10 \%)$ & 1 & \\
\hline$>20$ cigarettes & $2(20 \%)$ & $0(0 \%)$ & 2 & \\
\hline
\end{tabular}

TABLE IV. RELATIONSHIP OF CIGARETTES SMOKED WITH THE OCCURRENCE OF CHANGES IN PROLIFERATIVE ACTIVITY IN THE BUCCAL MUCOSA (> 4 AGNOR)

\begin{tabular}{|c|c|c|c|c|}
\hline \multirow{2}{*}{$\begin{array}{l}\text { Type of } \\
\text { Cigarettes }\end{array}$} & \multicolumn{2}{|c|}{$\begin{array}{c}\text { Changes of Proliferative } \\
\text { Activity in the Buccal Mucosa }\end{array}$} & \multirow[t]{2}{*}{ Total } & \multirow{2}{*}{$\begin{array}{c}\mathbf{P} \\
\text { Value }\end{array}$} \\
\hline & Yes & No & & \\
\hline $\begin{array}{l}\text { White } \\
\text { Cigarettes }\end{array}$ & $5(50 \%)$ & $0(0 \%)$ & 5 & 0.549 \\
\hline $\begin{array}{l}\text { Indonesian } \\
\text { clove } \\
\text { cigarettes }\end{array}$ & $5(50 \%)$ & $0(0 \%)$ & 5 & \\
\hline
\end{tabular}

The results of unpaired t-test analysis in Table 5 shows a significant difference $(\mathrm{P}=0.0001)$ with $\mathrm{p}$ $<0.05$ between the average value and standard deviation of AgNOR on nuclear proliferation activity of epithelial cells in the buccal mucosa of smokers and nonsmokers. The average AgNOR were 4.1610 in smokers and less than 2.1180in non- smokers. This suggests that the research hypothesis was accepted which means the activity of proliferation in the nucleus of epithelial cells in smokers was higher when compared to the activity of proliferation in nucleus of epithelial cells in nonsmokers.

TABLE V. MEAN AND STANDARD DEVIATION VALUES OF AGNOR IN EXFOLIATIVE CYTOLOGY IN NORMAL BUCCAL MUCOSA OF SMOKERS AND NON SMOKERS

\begin{tabular}{|c|c|c|c|}
\hline Sample & $\begin{array}{c}\text { Total } \\
\text { (sample) }\end{array}$ & $\begin{array}{c}\text { AgNOR Calculations } \\
\text { Mean +/-SD }\end{array}$ & P value \\
\hline Smoker & 10 & $4.1610+/-0.59$ & \multirow{2}{*}{$0,0001^{*}$} \\
\hline Non-smoker & 10 & $2.1180+/-0.41$ & \\
\hline
\end{tabular}

\section{DISCUSSION}

According to Sitepoe, a person will become a smoker through two impulses. First, it is through a psychological push similar to sexual stimulation, as a ritual, demonstrating masculinity, diverting anxiety, and showing maturity. Secondly, it is through the physiological impulse caused by the presence of nicotine that can lead to addiction to smoking. Psychological and physiological factors affect the smoking habit of many respondents. The respondents in this study were groups of students and workers and were at the age group with higher stress level. In this study, most of the respondents $(80 \%)$ had been smoking for $10-15$ years and $20 \%$ of respondents had been smoking for over 15 years. This was because most of the research samples were students. Most of them found it hard to quit smoking because they have been smoking for so long that they were addicted to cigarettes. 
Based on the number of cigarettes smoked per day, it was found that most respondents smoke 10-15 cigarettes a day with percentage of $70 \%$.This was because most of the respondents were students who were prohibited to smoke in the lecture hall. This was different from the respondents who smoke more than 20 cigarettes per day. This is due to general habit that when one employee smokes, other employees around will also participate in smoking. This is caused by a strong addiction to cigarettes. In this study, it was found that the type of cigarette normally used by nonacademic employees and students were white and clove cigarettes $(50 \%$ each). This result was different from the research conducted by Kaur, M (2013) who found that $64.71 \%$ of smoker prefered clove cigarettes which contained higher level of nicotine compared to white cigarettes. Clove cigarettes are also said to be more palatable than white cigarettes due to the anesthetic effect of eugenol ingredients added in the kretek cigarette, although the smoke is more dangerous when inhaled deeply.

The study found that $100 \%$ of smokers had changes in proliferative activity, while only $10 \%$ of non-smokers had changes in proliferative activity. This means that all smoker samples and one non-smoker sample had a value of $>3 \mathrm{AgNOR}$, which might be due to secondary smoking, spicy food eating habits and also the impact of drinking tea or hot coffee. According to a study from Turkey, the effects of direct irritation of hot tea could be the reason for higher proliferation ability of normal cells [12].

In this study, the relationship between duration of smoking, number of cigarettes inhaled per day and the kind of cigarettes did not show significant difference and the relationship between duration of smoking, number of cigarettes smoked per day and the kind of cigarettes did not show significant difference in the system computer data processing but a change in terms of pathological were apparent in smokers who had smoke for more than 15 years with $>4$ AgNOR, while two samples of smokers with 10-15 year period of smoking environment does not show cells that with $>4$ AgNOR. Smokers who smoke 20 cigarettes a day show AgNOR count of 5-6 per nucleus compared to smokers who smoke 10-15 cigarettes per day with only 3-4 AgNOR count. This was caused by the stimulation of old cigarette smoke that can cause damaging changes in the mucosa of the affected mouth. The oral mucosa of smokers which was exposed longer will change due to the chronic exposure process.

Of 5 sample cigarette users, 2 samples did not show nucleus with> $4 \mathrm{AgNOR}$. While on the cigarettes, five samples showed nuclei with> 4 AgNOR. This was because the content of nicotine in clove cigarettes is higher than white cigarettes. In clove cigarettes there is no filter for the content of nicotine into the oral cavity. Recent studies have shown that nicotine, a component of cigarette smoke, can stimulate the proliferation of non-neuronal cells. Nicotine has a carcinogenic power that induces cell proliferation and angiogenesis, but nicotine does not cause the development of healthy cells into cancer cell [19].

A significant difference was found in the average number of AgNOR between smokers and non-smokers with $\mathrm{P}<0.0001$ ( $\mathrm{P}<0.05)$. The percentage of nucleus with $>3$ AgNOR in smokers was higher than nonsmokers, this was due to higher proliferation rate in smokers. The results of this study indicated that smoking may cause changes in cell proliferation activity and other studies had also shown similar results. Raw value to determine between normal and malignant cells was 4 . Pavanello reported that smokers showed greater amounts of inflammatory changes as well as an increase in cell maturation rate. These changes, even with no clinical manifestations, show modifications to epithelial cells in response to the physicochemical environment caused by the smoke content of cigarettes. These results suggested that smoking produces a change in the cell proliferation mechanism. Tobacco has been considered to be a factor that induces the process of oral carcinogenesis. The results showed that the oral mucosa was susceptible to effects caused by smoking, which compensated/ responded by increasing cell proliferation [20].

The AgNOR technique used has shown a correlation between the number of AgNOR per nucleus and the smoking habit of the respondents. In this study, the results were lower than average in AgNOR calculation, clustered distribution of the cell, and formation of AgNOR round in both groups which are the characteristic of benign cells. It was compatible with the clinical aspects of normal buccal mucosa in smokers and non-smokers. The number of AgNOR per nucleus in smoker smears was higher when compared with nonsmoker smear. A higher frequency of $>3$ AgNOR per nucleus in smokers was indication of higher proliferation activity [13].

In the smears obtained from this study, AgNOR was observed as a perfect black spot in the nucleus. The calculation of AgNOR from each object glass takes about 10 minutes. The number of cells obtained from each smear exceeds requirements for microscopic analysis. This proves the efficiency of cytobrush technique in lifting epithelial cells. In addition, several specimens indicated the existence of debris on glass objects. Debris was round and black with different sizes. This was probably caused by the presence of debris on the glass objects or in the oral cavity of research subjects. This may also be due to ineffective gargling procedure or incomplete removal of debris with application of wet cotton in the mucosal area prior to cell removal procedure.

AgNOR staining was performed based on Ploton method with a slight modification that was adjusted to the laboratory conditions, in which glass objects were not immersed in a solution of AgNOR for incubation. The AgNOR solution was dropped onto the glass objects. This study requires 30 minutes of staining time.

It is concluded that there is a significant association between smoking and an increase in cell proliferation 
activity of the oral mucosa in smokers, and AgNOR staining is effective in investigation of pre-cancer lesions.

\section{REFERENCES}

[1] M. Eriksen, J. Mackay J, H. Ross, The tobacco atlas. $4^{\text {th }}$ ed. New York: World Lung Foundation, 2012, pp. 19-63.

[2] WHO. (2012, Jul 5) Konsumsi rokok di Indonesia 225 miliar batang per tahun. Available: http://www.suaramerdeka.com/ vl/index.php/read/news/ 2010/ 05/31/558-29/WHO-KonsumsiRokok-di-Indonesia--225-Miliar-Batang-per-Tahun

[3] S. Barber. (2010, August 7) Aspek ekonomi tembakau di Indonesia. Ekonomi tembakau di Indonesia. Available: www.worldlungfoundation.org.

[4] V. Trandafir, "Tobacco-induced oral mucosal modifications," Oral Pathology, vol. 1, pp. 84-91, 2011.

[5] N.W. Johnson, "Tobacco and oral disease," British Dental Journal, vol. 189, pp. 200-205, 2000.

[6] R.A. Cawson, E.W. Odell, Cawson's essentials of oral pathology and oral medicine. $8^{\text {th }}$ ed. Philadelphia: Churchill Livingstone Elsevier, 2008, pp. 261-289.

[7] A. Chandra. (2009, November 26) How smoking affects the mouth. Available: www.virtualmedicalcentre.com/healthandlife style/how-smoking-affects-the-mouth/239.

[8] J.A. Regezi, Oral pathology clinical pathologic correlations. $5^{\text {th }}$ ed. Missouri: Elsevier, 2008, pp. 44-55.

[9] R. Mehrotra, S. Yadav, "Oral squamous cell carcinoma: Etiology, pathogenesis and prognostic value of genomic alterations," Indian Journal of Cancer, vol. 43, pp. 60-61, 2006.

[10] U.S.T.A Ufuk, B. Ufuk, Evaluation of cytological alterations in normal-appearing oral mucosal epithelia ofs and non-smokers Via AgNOR Counts and Nuclear Morphometry, Trakya Univ Tip Fak Derg, 2008, pp. 110-116.

[11] S. Jahanshah, "Evaluation of AgNOR staining in exfoliative cytology of normal oral (buccal) mucosa: Effect of smoking," Journal of Mashhad Dental School, vol 31, pp. 22-24, 2007.

[12] P. Agus, "The pattern of p53 gene mutations on oral squamous cell carcinoma," Dent. J. (Maj.Ked.Gigi), vol. 40, pp. 119, 2007.

[13] P. Renata, "Comparative analyses between the smoking habit frequency and the nucleolar organizer region associated proteins in exfoliative cytology of smokers's normal buccal mucosa," Tobacco Induced Diseases, vol. 2, pp. 43-47, 2004.

[14] V.Y. Wei-Chung, "Potential biomarkers for the cytologic diagnosis of oral squamous carcinoma," J. Dent. Sci., pp. 60$61,2010$.

[15] V. Dinesh, J.V. Rajput, "Early detection of oral cancer: PAP and AgNOR staining in brush biopsies," Journal of Oral and Maxillofacial Pathology, pp. 52-58, 2010.

[16] S. Maryam. "Nucleolar organizer region-associated proteins in cytological smears of normal oral mucosa: The effects of smoking," Research Journal of Biological Sciences, pp. 750$755,2010$.

[17] M. Sitepoe, Kekhususan rokok Indonesia, Jakarta: PT Grasindo, 2000, pp. 1-34.

[18] M. Kaur, "Hubungan kebiasaan merokok dengan terjadinya coated tongue pada pegawai non-akademik Universitas Sumatera Utara," Tesis. Medan: Program Studi Kedokteran Gigi FKG USU, 2013, pp. 24.

[19] G. Taybos, "Oral changes associated with tobacco use". Abstract. American Journal of Medical Sciences, pp. 179-182, 2003.

[20] P.C. Fontes, "Comparison of exfoliative pap stain and AgNOR Counts of the tongue in smokers and non smokers," Head and Neck Pathol, pp. 157-162, 2008. 